\title{
What happened in there? Confessions, credibility and automatic exclusion: the case of Artt and confession admissibility
}

\author{
Eamonn Rea, Barrister-at-Law \\ Queen's University Belfast \\ Correspondence email: ereao6@qub.ac.uk
}

\begin{abstract}
Confessions ought to be excluded if it is shown that credibility of the police's version of events at interview is disputed, and it is found procedural requirements relating to recording of interviews under Police and Criminal Evidence Act 1984 Codes were not observed.

This article posits that, where the assessment of what occurred in an interview room depends on the trial judge's assessment of the accused's credibility versus the police's credibility, a breach of the relevant Codes should mean a trial judge should doubt the police's version of events and prefer the accused's version of events. This leads to the exclusion of the confession.

While giving particular attention to the recent Northern Ireland Court of Appeal decision of $R v$ Kevin Artt, this article suggests a policy that can apply to jurisdictions beyond the Northern Irish jurisdiction, especially where recording of interviews is not routine. Analogies will be made with similar provisions in the United States where appropriate.
\end{abstract}

Keywords: Northern Ireland; confessions; admissibility; recordings; Code C breaches; Code E breaches; Code F breaches; credibility.

\section{INTRODUCTION}

The power of a confession can be such that it is damning to the defence's case in a criminal trial; but it ought to be potentially damning, too, for the prosecution's case if it is shown that the confession was obtained and procedural requirements under Police and Criminal Evidence Act 1984 (PACE) Codes C, E or F were not observed adequately, but only if and when credibility of the police witnesses is brought into question.

While some may see some procedural requirements under the PACE Codes as unrelated to the reliability of a confession and therefore ought to have nothing to do with the confession's admissibility, this article makes the proposition that the procedural requirements of Code C, E and $F$ related to the recording of interviews should be stringently followed; 
if they are not, and credibility of the police is brought into question in the voir dire, the confession should be excluded automatically.

Under the present law, the confession may only be excluded due to a breach of the Codes if the trial judge sees fit under the discretionary power of article 76 of the Police and Criminal Evidence (Northern Ireland) Order 1989, and sometimes under article 74(2)(b) of that statute. This article argues that this present standing of the law does not go far enough in protecting an accused who alleges the police are being untruthful in their evidence in some form or another, and who faces the danger of a wrongful conviction if the trial judge decides to believe the police version of events at trial over the accused's own. This article posits that, where the assessment of what really occurred in an interview room depends on the trial judge's assessment of the accused's credibility versus the police's credibility, a breach of Codes C, E or F in relation to recording of interviews should mean a trial judge should doubt the police's version of events and prefer the accused's version of events. If the latter's version of events of what went on in the interview room would lead to the resultant confession being made inadmissible, this should be so done automatically.

Though this article mainly applies, as far as the Northern Ireland and the English and Welsh jurisdictions are concerned, to cases on appeal that were tried pre-PACE, the article's suggestions can apply to present-day jurisdictions where those jurisdictions still do not have routine recordings of police interviews.

The first part of this article - 'Recording of interviews and the admissibility of the confession' - highlights the importance of the Codes in relation to the recording of interviews, before discussing the current admissibility law of confessions in relation to the breach of those provisions in the Northern Irish and in the English and Welsh jurisdictions. The second part - 'Good confessions rendered bad: an injustice?' - explores the argument that any expansion of the law in this discrete area may lead to perfectly valid confessions being excluded for want of bureaucratic, red-tape 'box-checks' found within the relevant Codes, leading to an acquittal on a technicality and arguably causing an injustice. The third part - 'Balancing injustice with justice: a compromise?' - will counter this and suggest that the potential for injustice over an acquittal of the guilty counters the graver possibility of an even greater injustice: the wrongful conviction of an innocent person. A potential 'third-way' approach will be examined as a compromise between the current PACE law and automatic exclusion - that of a rebuttable presumption in favour of the defendant - which is seen in some United States (US) jurisdictions. The suitability of such a third way will be discussed and ultimately rejected. 
The fourth part will discuss the role of the Northern Ireland Court of Appeal decision of $R v$ Kevin Barry Artt in illustrating the need for automatic exclusion. It is argued that the time has come for an expansion of the law in relation to the unreliability of a confession. It is posited that a breach of Codes $\mathrm{C}, \mathrm{E}$ and $\mathrm{F}$ in relation to the recording of interviews must exclude the confession if credibility is a live issue and cannot be left to the current law's reliance on a trial judge's discretion under article 76 of the Police and Criminal Evidence (Northern Ireland) Order 1989.

\section{RECORDING OF INTERVIEWS AND THE ADMISSIBILITY OF THE CONFESSION}

A confession statement under Northern Ireland law can be excluded, broadly, for three reasons: due to oppression (of the confessor) $;^{1}$ due to unreliability (of the confession) ${ }^{2}$ or due to the fact that, having regard to all the circumstances, including the circumstances in which the evidence was obtained, the admission of the evidence would have such an adverse effect on the fairness of the proceedings that the court ought not to admit it. ${ }^{3}$ While the first two categories provide that the confession must be excluded if the prosecution fails to discharge its burden of proof, the third category, often referred to as 'fairness', is a discretionary power of the trial judge that is frequently used as a safety net for a defendant's arguments if the confession statement was not obtained via oppression, nor by means that affect its reliability.

As shall later be seen, it is recognised in the jurisprudence that a breach of the Codes can impact the decision whether or not to exclude an obtained confession statement within the framework of the above statutory provisions. This article is not, however, concerned with a breach of the Codes in all their forms; rather, it is concerned with Codes $\mathrm{C}, \mathrm{E}$ and $\mathrm{F}$, which relate to the recording of interviews of a suspect conducted by police. Although Code C concerns the entirety of the governance of a suspect's detention, questioning and treatment in police custody, this article is specifically concerned with those aspects of Code $\mathrm{C}$ relating to the recording of interviews conducted by police in pursuing the investigation of a suspected offence; Code C paragraphs 11.7-11.14 are aimed towards ensuring accurate and, where possible, contemporaneous 
note-recordings of these interviews. ${ }^{4}$ Code $\mathrm{E}$ concerns the audiorecording of interviews relating, generally, to any indictable offence, 5 unless there is an equipment failure or unavailability of an interview room with equipment, and the authorising officer considers the interview should not be delayed until those issues are rectified. 6 In such a case, the requirements of Code $\mathrm{C}$ in relation to the recording of interview notes must be observed. Code $\mathrm{F}$ contains similar provisions for the videorecording of interviews. Though video-recording is not compulsory, it might be considered appropriate to video-record under similar criteria as found in Code E, which requires mandatory tape-recordings. ${ }^{7}$

The raison d'être of Code E can be found in the Police and Criminal Evidence (NI) Order itself concerning the tape-recording of interviews; 8 a 2007 amendment provided for the video-recording, with sound, of all police interviews, thus requiring the creation of Code F. ${ }^{9}$

Paras 11.7 to 11.14 of Code $\mathrm{C}$ provide that: an accurate record must be made of each interview, whether or not the interview takes place at a police station; the record must state the place of interview, the time it begins and ends, any interview breaks and, subject to para 2.6A, the names of all those present; these must be made on the forms provided for this purpose or in the officer's note book or in accordance with the Codes of Practice E or F; any written record must be made and completed during the interview, unless this would not be practicable or would interfere with the conduct of the interview, and must constitute either a verbatim record of what has been said or, failing this, an account of the interview which adequately and accurately summarises it; that if a written record is not made during the interview it must be made as soon as practicable after its completion; written interview records must be timed and signed by the maker; if a written record is not completed during the interview the reason must be recorded in the interview record; unless it is impracticable, the person interviewed shall be given the opportunity to read the interview record and to sign it as correct or to indicate how they consider it inaccurate. If the person interviewed cannot read or refuses to read the record or sign it, the senior interviewer present shall read it to them and ask whether they would like to sign it as correct or make their mark or to indicate how they consider it inaccurate. The interviewer shall certify on the interview record itself what has occurred; if the appropriate adult or the person's solicitor is present during the interview, they should also be given an opportunity to read and sign the interview record or any written statement taken down during the interview; a written record shall be made of any comments made by a suspect, including unsolicited comments, which are outside the context of an interview but which might be relevant to the offence. Any such record must be timed and signed by the maker. When practicable the suspect shall be given the opportunity to read that record and to sign it as correct or to indicate how they consider it inaccurate; any refusal by a person to sign an interview record when asked in accordance with this Code must itself be recorded.

Ibid paras [3.1]-[3.2].

6 Ibid para [3.3A].

7 Ibid paras [3.1]-[3.6].

8 Police and Criminal Evidence (Northern Ireland) Order 1989, art 60.

9 Ibid art 60A, inserted by Police and Criminal Evidence (Amendment) (Northern Ireland) Order 2007. 


\section{The importance of the recording of interviews in the context of confession admissibility}

What, then, is the importance of these Codes? Combined, it has been said that the Codes' overriding purpose is the protection of those who are vulnerable because they are in the custody of the police, 10 and it is in this context that the purpose of relevant parts of Code C, along with Codes E and F, should be seen. Together, these parts of the Codes are collectively aimed towards the contemporaneous, accurate and objective recording of interview content, be it as a live-recorded tape-recording or video-recording, or as a note taken of the interview. Assuming contemporaneous, accurate and objective recordings of interview content are made, then this evidence has its weight increased, for it cannot be doubted nor disputed; it is a matter-of-fact statement of both the occurrences and utterances in the interview room. ${ }^{11}$ This can be crucial to proving a confession's reliability and admissibility.

The fact that the recordings provide irrefutable evidence of what occurred in the interview room provides protection to both the police and to the suspect, 12 for one party cannot accuse the other of doing something that did not in fact occur, and so evidence cannot be fabricated by either side, which would often lead to a 'swearing contest' between the suspect and police. ${ }^{13}$ Such fabrication and 'swearing contests' would cause practical problems, leading to lengthy voir dire hearings that require a tribunal of law to determine what precisely occurred in an interview room via hearing of evidence from the suspect and the interviewing police before the actual evidence of the trial proper, and, as shall be seen, frequently requires the tribunal of law to make an assessment of each side's credibility, which can often be a very dangerous task. After this hurdle has been overcome, the tribunal of law must then determine how that assessment of facts impacts the law on the admissibility of the confession, taking into account submissions relating to admissibility from counsel for each party, who are relying on their own respective accounts of what occurred in the interview room. This creates inherent and lingering doubt in the trial process as to what

$10 R$ v Jelen and Katz (1990) 90 Cr App R 456, 465 (Auld J).

11 Thomas P Sullivan, 'The time has come for law enforcement recordings of custodial interviews, start to finish' (2006) 37(1) Golden Gate University Law Review 175.

12 Although it has been argued that the contrary occurs with the suspect not being able to effectively challenge the interviews. See M K Kaiser, 'Wrongful convictions: if mandatory recording is the antidote, are the side effects worth it?' (2014) 67(1) Arkansas Law Review 167; M Ibusuki, 'The dark side of visual recording in the suspect interview: an empirical and experiential study of the unexpected impact of video images' (2019) 32 International Journal for the Semiotics of Law 831.

13 R A Leo, Police Interrogation and American Justice (Harvard University Press 2008). 
actually went on in the interview room, regardless of what decision the trial judge takes. Such doubt can form the basis of an appeal of a subsequent conviction on the basis of fresh evidence applications, or, if an appeal is not pursued, can leave unjust and erroneous convictions left never to be discovered. ${ }^{14}$ Instead, if accurate recordings of interviews are made, this means that the court's attention and time is concentrated on other key issues in the case, saving court time and costs, and also releasing the defendant from much anxiety and anticipation.

As allowed by Codes $\mathrm{E}$ and $\mathrm{F}$, however, sometimes only a written record is made of the interview process. But problems can arise from dismissing the need for video or tape-recordings and instead solely relying upon interview notes drawn up - even shortly - after the interview itself. A study by Kassin et al found that, when police made reports from memory about what occurred during unrecorded interrogations, they frequently made errors, omitted information and understated their use of several controversial and/or problematic interrogation techniques, such as false evidence ploys and implied promises of leniency; ${ }^{15}$ the most sinister of these will be seen in the case of Artt discussed later in this article. There is less likelihood of these sinister tactics occurring if the interview is video or taperecorded, 16 and this is especially required in combatting interviewers' presumptions of guilt, which typically see a more aggressive form of interviewing taking place, ${ }^{17}$ and which could in turn result in false confessions being obtained. It is worth noting that while video or taperecording of interviews positively affects the interviewers' approach, it does not negatively inhibit suspects from confessing, nor does it influence their behaviour during interviews in general, 18 whereas these undesirable approaches that the interviewers sometimes take (by

14 University of California Irvine Newkirk Center for Science and Society, University of Michigan Law School and Michigan State University College of Law, National Registry of Exonerations Project (2020).

15 S Kassin, J Kukucka, V Z Lawson, and J DeCarlo, 'Police reports of mock suspect interrogations: a test of accuracy and perception' (2017) 41(3) Law and Human Behavior 230.

16 S Kassin, J Kukucka, V Z Lawson and J DeCarlo, 'Does video recording alter the behavior of police during interrogation? A mock crime-and-investigation study' (2014) 38(1) Law and Human Behavior 73; S M Kassin, S A Drizin, T Grisso, G H Gudjonsson, R A Leo and A D Redlich, 'Police-induced confessions: risk factors and recommendations' (2010) 34(1) Law and Human Behavior 3.

17 S Kassin, C Goldstein and K Sav, 'Behavioral confirmation in the interrogation room: on the dangers of presuming guilt' (2003) 27(2) Law and Human Behavior 187.

18 S Kassin, M Russano, A Amron, J Hellgren and J Kukucka, 'Does video recording inhibit crime suspects? Evidence from a fully randomized field experiment' (2019) Law and Human Behavior 43, 45-55. 
adopting more aggressive and coercive methods of interviewing) have long been accepted in the literature to contribute towards possibly producing the psychological phenomenon of false confessions. ${ }^{19}$

It is true that such approaches to interviews can be changed not just by the recording of the interview, but by the adoption of more reliable, open-minded and ethical interviewing methods, such as the cognitive interview technique-led adaptability model used in the Irish Republic, ${ }^{20}$ or the well-regarded PEACE method as preferred in the United Kingdom (UK), ${ }^{21}$ which seek to minimise the occurrences of false confessions and are preferable in achieving this over methods such as the US-advocated Reid technique. ${ }^{22}$ But just because more reliable techniques - such as the PEACE method in the UK - are endorsed, this does not mean they are always employed,23 and subsequently there is still a risk of false confessions occurring where more coercive techniques appear in the PEACE model's stead.

Regardless too of the interview method undergone, where recording of interviews is not done and instead the record is found in interview notes, problems exist. Memory recollection in writing up interview notes in the absence of a recording is an obvious inhibitor. The order of items of questioning can be innocently forgotten by interviewers, or omitted altogether, again innocently, due to a lapse in memory entirely. One study found that more than half (57 per cent) of the interviewers' utterances along with 25 per cent of the incident-relevant

19 S M Kassin and K L Kiechel, 'The social psychology of false confessions: compliance, internalization, and confabulation' (1996) 7(3) Psychological Science 125; R Ofshe and R Leo, 'The social psychology of police interrogation: the theory and classification of true and false confessions' (1997) 16 Studies in Law, Politics and Society, 189; R Ofshe and R Leo, 'The decision to confess falsely: rational choice and irrational action' (1997) 74 Denver University Law Review 981; R Leo, 'False confessions: causes, consequences and implications' (2009) 37 Journal of the American Academy of Psychiatry and the Law 332.

20 R P Fisher and V Perez, 'Memory-enhancing techniques for interviewing crime suspects' in S A Christianson (ed), Offenders' Memories of Violent Crimes (Wiley 2007) 329-254.

21 B Snook, J Eastwood and W Todd Barron, 'The next stage in the evolution of interrogations: the PEACE model' (2014) Canadian Law Journal 220, 230; D Walsh and R Bull, 'What really is effective in interviews with suspects? A study comparing interviewing skill against interviewing outcomes' (2010) 15 Legal and Criminological Psychology 305.

22 G Gudjonsson and J Pearse, 'Suspect interviews and false confessions' (2011) 20(1) Current Directions in Psychological Science 33-37; see more generally B Snook et al, 'Urgent issues and prospects in reforming interrogation practices in the United States and Canada' (2020) Legal and Criminal Psychology 7-8.

$23 \mathrm{~J}$ Pearse and G H Gudjonsson, 'Measuring influential police interviewing tactics: a factor analytic approach’ (1999) 4 Legal and Criminological Psychology 221. 
details provided by the interviewee were omitted from the would-be verbatim interview notes. ${ }^{24}$ Details of an interview omitted or included in a record will, it has been found, shape juries' findings, ${ }^{25}$ and so the repercussions of non-contemporaneous and non-accurate interview notes can be critical.

Taking the best case scenario in the alternative by assuming that memory recollection is not an issue and the interview notes are verbatim, there is still a problem from a linguistics study perspective, due to contamination between oral language and written language. ${ }^{26}$ Written language is devoid of voice modulation - aspects such as intonation, volume and tone are all omitted from even the most faithfully recorded interview notes, especially if such information is written as a summary of the interview process. These factors may, on a case-by-case basis, be used by defence counsel to argue that a confession is unreliable, and thus potentially lead to its exclusion from the evidence. Routine video and tape-recording, however, nullifies this concern and makes confessions more reliable, although the ground of unreliability would still be open to defence counsel, as shall later be seen. Certainly at least, the routine video and tape-recording of the interviews means there is an indisputable basis upon which the prosecution and defence can concur are agreed facts, thus narrowing the basis of contested matters and potentially then enhancing the examination into the confession statement's admissibility.

Lastly, it is likely that the aforementioned reasons contribute to greater public confidence in the transparency and infallibility of taperecorded or video-recorded interview processes as opposed to nonelectronic recording. ${ }^{27}$ This can especially be important in societies where in the past the police had gained notoriety in their interviewing and interrogation practices, such as in the Northern Irish jurisdiction during the Troubles. ${ }^{28}$

24 M Lamb, Y Orbach, K Sternberg, I Hershkowitz and D Horowitz, 'Accuracy of investigators' verbatim notes of their forensic interviews with alleged child abuse victims' (2000) 24 Law and Human Behavior 699.

$25 \mathrm{~J}$ Keijser et al, 'Written records of police interrogation: differential registration as determinant of statement credibility and interrogation quality' (2011) 18(7) Psychology, Crime and Law 613.

26 K Haworth, 'Police interviews as evidence' in M Coulthard and A Johnson (eds), Routledge Handbook of Forensic Linguistics (Routledge 2010).

27 T P Sullivan, 'Electronic recording of custodial interrogations: everybody wins' (2005) 95(3) Journal of Criminal Law and Criminology 1127.

28 See eg I Cobain, Cruel Britannia: A Secret History of Torture (Portobello Books 2012) ch 6. 
Thus, while this commentator and others ${ }^{29}$ advocate, for the above reasons, the compulsory recording of police interviews either via tape or via video-recording and argue that recording requirements are, for those reasons, important, it has been less explored as to how a breach of those important requirements impacts, or should impact, on the admissibility of an associated confession.

How, then, does the current law in Northern Ireland and the English and Welsh jurisdiction treat a breach of the Codes, insofar as they relate to the recording of interviews, in the context of a confession's admissibility? It is to this question that this section now turns.

\section{On grounds of oppression}

It is submitted that a procedural breach of the Code cannot be 'oppression' under the general meaning of that term per article 74(8) of the Police and Criminal Evidence (Northern Ireland) Order 1989, which speaks to matters including torture, inhuman or degrading treatment; a procedural breach of the Codes cannot come close to this standard and so only the grounds of unreliability and the discretionary power remain as avenues for exploration when a breach of Codes $\mathrm{C}, \mathrm{E}$ and $\mathrm{F}$ in relation to recording of interviews occurs.

\section{On grounds of unreliability}

The unreliability route under article 74(2)(b) of the Police and Criminal Evidence (Northern Ireland) Order 1989 is less straightforward than that of oppression where a breach of recording requirements under the Codes is concerned. An argument that a confession is rendered unreliable due to something not done (specifically that the strict observation of Code C, E or F was not done by the police) is hindered for several reasons.

Firstly, the wording of article 74(2)(b) implies the more usual commission of something said or done, rather than the omission of something that ought to have been said or done (although the omission of keeping a proper record of the interview was entertained for the purposes of article 74(2)(b) in the case of Doolan ${ }^{30}$ and the case of Delaney), 31 and this may necessitate the need to word the argument of an omission in positive terms. ${ }^{32}$ This can complicate the submissions being made linguistically, but more importantly it impedes the

29 See eg Sullivan (n 11); G D Lassiter and M Lindberg, 'Video recording custodial interrogations: implications of psychological science for policy and practice' (2010) 38(1) Journal of Psychiatry and Law 177.

30 [1988] Crim LR 747, CA; see also $R v$ Barry (1991) 95 Cr App R 384, CA.

31 (1988) 88 Cr App R 338.

32 See D Ormerod and D Perry (eds), Blackstone, Criminal Practice (Oxford University Press 2015) F17.24. 
argument that an omission positively affected the reliability of a confession. It is far easier to argue that something that the suspect witnessed being positively said or done (in other words, a commission) affects the confession's reliability, than it is to argue that something he or she did not witness said or done (an omission) affected the reliability of that confession.

Secondly, it is difficult for counsel to argue that the interviewing police officers omitting to follow the Codes contributes to the reliability of a confession to the extent it 'cannot be relied upon as being the truth'. 33 This is because the Codes would normally be observed by police without the suspect ever being aware of it, and the question therefore begs how a confession's reliability can be questioned if it does not affect a suspect's actual decision to confess. Indeed, the conduct alleged to undermine the reliability of the confession must have some causal link to the making of that confession, as seen in the cases of Beales ${ }^{34}$ and Goldenberg, ${ }^{35}$ as well as being made implicit in the statutory wording itself. 36 This also was the general position of the old common law. ${ }^{37}$ Such a causation link between Code breaches and unreliability of the confession is difficult.

Thirdly, and in any event, the courts have demonstrated a preference in practice of dealing with breaches of PACE Codes under article 76's discretionary exclusion as opposed to the ground of unreliability. ${ }^{38}$ This can mean that any arguments concerning a breach of the Codes in relation to recording of interviews made in an application by the defence to exclude the confession under article 74(2)(b) is blunted from the onset and denies the defendant a chance to exclude the confession automatically due to a breach of the Codes.

\section{On discretionary grounds}

The courts' preference for article 76 of the Police and Criminal Evidence (Northern Ireland) Order 1989 when it comes to dealing with breaches of the Codes means that cases where submissions mainly depend

$33 \quad R v$ Crampton (1990) 92 Cr App R 369, 372.

34 (1992) 95 Cr App R 384.

35 (1989) 88 Cr App R 285.

36 Police and Criminal Evidence (Northern Ireland) Order 1989, art 74(2), which reads '[it] was or may have been obtained ... in consequence of anything said or done'.

37 DPP $v$ Ping Lin [1976] AC 574, at 601

38 See $R v$ Sparks [1991] Crim LR 128; see also W Twinning, Rethinking Evidence: Exploratory Essays 2nd edn (Cambridge 2006) 223; M Redmayne, 'The structure of evidence law' (2006) 26 Oxford Journal of Legal Studies 805, 807, where it is argued there has been a 'drift away from exclusionary rules ... especially after the Criminal Justice Act 2003’. 
on a breach of the Codes fall to be decided within the realm of the discretionary grounds here.

The question of whether or not these breaches ought to render the confession inadmissible depends on their degree of 'adverse effect' on the 'fairness' of the proceedings. ${ }^{39}$ This seems to imply a two-pronged approach for judges to consider in the voir dire: firstly, whether or not the omission of adherence to Codes $\mathrm{C}, \mathrm{E}$ or $\mathrm{F}$ created an adverse effect prima facie, and, secondly then, the degree to which this adverse effect affected the fairness of the proceedings. ${ }^{40}$ This appears to be a balancing act between fairness to the accused and fairness to the prosecution, although prima facie it seems fairness to the accused will have been prejudiced where major Code breaches are concerned.41 Nevertheless, like article 74(2)(b), it appears that a causation link needs to be established between the breach of the relevant Codes and the resulting confession. ${ }^{42}$ As discussed above, this can be the main sticking point in arguing that a breach of the Codes led to the making of a confession, and it certainly is clear that the mere fact that there has been a breach of the Codes does not of itself mean that evidence has to be rejected; 43 any argument pertaining to a breach of the Codes therefore needs to be developed and proved evidentially by the defence and done so persuasively for the trial judge to exercise his or her discretion.

Of course, the further issue with admissibility arguments focused towards article 76 - being a discretionary power - is that subsequent appeal is difficult. Discretionary powers mean that the fettering of the trial judge's decision on appeal is slight, the standard being one of Wednesbury unreasonableness in effect. ${ }^{4}$ Indeed, the case law in this area accepts that judges may take different views in how to properly exercise their discretion, even when counsel make parallels between their case and cases gone before, 45 and the Court of Appeal in England and Wales has been reluctant to provide any general guidance to how a trial judge should approach that jurisdiction's equivalent to article 76.46 All these factors make it less likely that an appeal court would interfere with a trial judge's discretion over article 76, especially

39 See $R v$ Alladice (1988) 87 Cr App R 380; $R v$ Walsh (1989) 91 Cr App R 161, 163.

$40 \quad$ See $R v$ Kerawalla [1991] Crim LR 252.

$41 \quad R v$ Walsh (n 39 above).

42 See Roberts [1997] 1 Cr App R 217, in which the Court of Appeal held that the breach of a code provision, which was designed to protect another suspect, had no causal link with the accused's own confession.

$44 \quad R v$ Quinn [1995] 1 Cr App R 480, 487.

45 Jelen and Katz (n 10 above).

$46 \quad R v$ Samuel [1988] QB 615. 
when the appeal panel has not had the benefit of observing the witnesses in a voir dire, and it is subsequently incredibly difficult to successfully argue the trial judge ought to have exercised his or her discretion. The net effect of this, where a conviction is secured solely or mainly on the basis of a confession, is that the defendant's safeguard of an appeal is diminished in power and significance where breaches of the Codes concerning recordings formed the backbone of the admissibility arguments.

In sum, successful arguments advocating for the inadmissibility of a confession due to the relevant Codes' breaches is next to impossible under the oppression category, and difficult under the unreliability category. It appears that courts have a preference for the discretionary route where it comes to Code breaches, but this route comes with its own problems: still a causation link is required, and the appeal safeguard is diminished.

It is suggested that this current standing of the law is unsatisfactory; the courts have not yet appreciated the link between the failure to record interviews adequately or at all, on one side, and the increased possibility of a false or coerced confession on the other. It is for these reasons that it is submitted that the current framework of the law is inadequate for protecting an accused from a confession being admitted into evidence against him or her in circumstances where the police evidence's reliability is challenged by the accused. ${ }^{47}$ However, it is appropriate first to consider in the following part the arguments against any expansion to the law in this area.

\section{GOOD CONFESSIONS RENDERED BAD: AN INJUSTICE?}

Having explored the current standing of the law in relation to breaches of the Codes and admissibility of the confession, this article now turns to considering the arguments against any expansion of the law.

These arguments fall broadly into three categories: the causation requirement; the suitability of the current law's scope for dealing with Code breaches; and the courts' desire to avoid disciplining or otherwise punishing the police for a failure to observe the Codes.

First is the argument that a breach of the relevant Codes may be minor and, in any event, does not bear consequence on the confession's validity. This argument is the strongest and most meritorious argument against any expansion of the current law because it reflects the present

47 Although Roberts argues that failure to record an interview in the context of disputes over the police's credibility will trigger art 76's discretionary powers. See P Roberts, 'Law and criminal investigation' in T Newburn, T Williamson and A Wright (eds), Handbook of Criminal Investigation (Willan Publishing 2007) 129. 
law's need for causation in both article 74 and article 76 submissions; in order for a confession to possibly be excluded, it must have been in some way contaminated by the actions or inactions of the police or someone else in authority. It is difficult to suggest that a minor breach of the Codes has so contaminated a confession; despite having a right to consult the Codes, suspects typically do not because they often fail to understand the Notice to Detained Persons, particularly regarding their right to consult the $\operatorname{Codes}^{48}$ and so are unlikely to be able to understand their rights fully, ${ }^{49}$ subsequently meaning they are usually oblivious to such breaches occurring. Though this is a criticism of the Notice's formation, it also follows then that the breach would have no bearing on a suspect's decision to confess or not, and therefore, it can be argued, a breach of the Codes should not come into the decisionmaking realm within a voir dire.

Secondly, the argument can be made that the current law is wide enough in its scope. As has been seen, there have been cases where a breach of the Codes has indeed led to exclusion of the confession. The fact that both the routes of article 74(2)(b) and article 76 are open to submissions on the breach of the Codes shows the current law's flexibility and accommodation for these types of cases. It is still open for counsel to argue that a breach of the Codes impacts on the reliability of the confession if appropriate, so long as the causation link is established. Failing this ground, tailored submissions to the case can be made appealing to the judge's article 76 discretionary powers. The discretionary powers can be a 'safety net' for cases that do not meet the unreliability standard and encompass a perhaps wider benchmark of 'fairness' that a judge can assess on a case-by-case basis. This ought to give counsel adequate scope to make arguments for a confession's exclusion, if it is appropriate to the case at hand.

Thirdly, is the argument that any failure to follow the Codes generally is a matter for discipline of the police, and the courts are not concerned with punishing or otherwise disciplining the police for Code breaches. ${ }^{50}$ Automatic exclusion of a confession due to a failure to observe the Codes would arguably amount to a 'punishment' setting that is not constructive for justice. Rather, the focus is, and should be,

48 The right to consult the Codes section of the Notice to Detained Persons was found to have been made more difficult to understand in the April 1991 revision of that Notice, from a Flesch score of 53 out of 100 pre-April 1991 to 37 out of 100 post-April 1991. See G Gudjonsson, I C H Clare and P Cross, 'The revised PACE “Notice to Detained Persons”: how easy is it to understand?' (1992) 32(4) Journal of the Forensic Science Society 289, 293-295.

$50 \quad$ See $R v$ Mason [1988] 3 All ER 481. 
on a criminal court striving to find the truth as to the accused's guilt or innocence to the best of its ability.

These three arguments together reflect the key concern for the court, which is its ability to determine whether the confession's contents are reliable or not. Notwithstanding breaches of the Codes, the confession could still be reliable and so ought to be admitted. Observers could see it as an affront to justice if a breach of the Codes' recording requirements occurred and, as a result, the defendant 'got off the hook', despite having made an otherwise valid confession, the perfectly good confession being rendered bad because of a box-ticking exercise, in the form of the Codes, not done by the police.

Yet the injustices potentially to be found in an expansion of the law, it is submitted, dwarf the even greater injustices that can potentially occur within the current framework. So far, this article has discussed the importance of recording of interviews and the adherence to Codes $\mathrm{C}$, $\mathrm{E}$ and $\mathrm{F}$ in relation to such recording. It has also suggested that there is an increased risk of false confessions being made and being overlooked where such recording is absent. These arguments are brought together in the third part of this article, where the main thrust of its proposition is made, before, in the fourth part, the arguments take illustration in the 2020 Court of Appeal in Northern Ireland decision of Kevin Artt.

\section{BALANCING INJUSTICE WITH JUSTICE: A COMPROMISE?}

As has been seen in the first part of this article, the exclusion of a confession due to a breach of the Codes is far from a home-run for the defence because, regarding article 74(2)(b), it will usually be in dispute with the prosecution how and to what extent the reliability of the confession is so undermined by a breach of the Codes due to the requirement for demonstrating a causation link. With regards to the discretionary power to exclude a confession under article 76, it was plainly stated by the Court of Appeal in England and Wales:

This does not mean, of course, that in every case of a significant or substantial breach of ... the codes of practice [that] the evidence concerned will automatically be excluded. ${ }^{51}$

Indeed, the very nature of article 76 and the standard the appellate courts will use to review use of same means that it is very hard to challenge the case-by-case discretion of the trial judge, who is making a judgment call in the voir dire as to how the breach of the Code affected the accused based on the case-specific circumstances. 52 
Herein lies the issue with the current law's standing: where the police claim one version of events in the interview room (but it is found that they breached Codes $\mathrm{C}, \mathrm{E}$ or $\mathrm{F}$ in relation to the recording of interviews) and the accused claims another version of events, the credibility of each side is brought to the forefront in the absence of an independent and reliable interview record, and so the trial judge must make a judgment call. But does the trial judge believe the multiple police interviewers, or does he or she believe the accused?

The answer obviously is that it depends on the case at hand, but this in turn will almost always depend on the trial judge's assessment of the credibility of the police witnesses versus the credibility of the accused in order to determine what occurred in the interview room, and this can sway in the police's favour where a defendant's bad character application is made 53 and may, in fact, always have the presumption that the police are telling the truth. 54 The problem, generally, is that one judge may decide to believe the police and admit the confession, and, were another judge sitting, the confession would have been excluded because that second judge would have believed the accused's versions of events. Judges may make the correct judgment call, but the very existence of a sophisticated appeal infrastructure in the common law world is tacit acknowledgment that trial judges do not always get it right.

Herein lies the problem and the chief contention of this article. Where a breach of the Codes in relation to recording of interviews is made and that provision is designed to protect an accused from fabrication by the police, the importance of those provisions should become paramount as a highlighted safeguard for the accused against the machinery of the state and its agents - in these circumstances, the police - if and when the version of events of the interview room is disputed between the accused and the prosecution. What is proposed is that, if credibility of the police's account of the interview and the circumstances leading to the confession is disputed, and a breach of the Codes in relation to recordings has resulted in the records not having been signed, made contemporaneously, or made at all, in the absence of an independent and reliable record of interview, the trial judge should err on the side of caution and believe the accused's version of events, thereby excluding the confession automatically on the grounds of its questioned unreliability or authenticity. While a breach of the Codes may be innocently done, the breach should heighten the suspicions

53 See R Moran, 'Contesting police credibility’ (2018) 93 Washington Law Review 1339.

54 See D Dorfman, 'Proving the lie: litigating police credibility' (1999) 26 American Journal of Criminal Law 455, 471-472. 
of the court regarding the good faith, and therefore reliability, of the police witnesses.

While the proposition of this article could in effect lead to guilty defendants waltzing free (and this is certainly an injustice), it avoids the greater injustice of an innocent defendant being convicted on the basis of - what turns out to be - an unreliable confession. This was the case for the appellant in the 2020 decision of $R v$ Kevin Barry Artt, 55 which will be examined in the next part. Firstly, however, it is appropriate to examine a possible compromise between the current law as found in $\mathrm{PACE}$ and its jurisprudence and the proposition of automatic exclusion this article advocates. A third-way compromise between these two can be seen in the US's treatment of confession statements in the context of interview recording, and such an examination provides an insight into similar provisions already in place there to those proposed in this article - but not to its fullest extent.

The US as a whole demonstrates a patchwork approach that varies across states as to the requirements over recording of interviews, although there seems to be a consensus in advocating for greater uniformity federal-wide. ${ }^{56}$ In many ways this development was, and is, behind the PACE provisions brought into effect in England and Wales and in Northern Ireland, in 1984 and 1989 respectively; prior to 2003, only two states - Alaska and Minnesota - required police officers to record custodial interrogations (now just over 50 per cent of states require recording of interviews in principle). 57 Alaska and Minnesota are both, however, states with a similar absolute exclusion rule as that proposed in this article; both states' respective supreme courts have ruled that testimonial evidence of what occurred during a custodial interview will be excluded from evidence if the prosecution is unable to establish a valid excuse for not making an electronic recording. 58 This may, or may not, include a verbal confession. While this article has proposed the automatic exclusion of the confession (verbal or written) resulting from the unrecorded interviews, the approach taken by these two states focuses on the interview record itself. However, this is still a provision which is close to the reasoning of this article's own proposal.

55 [2020] NICA 28.

56 Lassiter and Lindberg (n 29); B Bang et al, 'Police recording of custodial interrogations: a state-by-state legal inquiry international' (2018) 20(1) Journal of Police Science and Management 3; A M Gershel, 'A review of the law in jurisdictions requiring electronic recording of custodial interrogations' (2010) 16(3) Richmond Journal of Law and Technology 1.

57 Bang et al (n 56 above) 10.

58 T Sullivan and A Vail, 'The consequences of law enforcement officials' failure to record custodial interviews as required by law' (2008) 99(1) Criminal Law and Criminology 215, 217. 
Across the other states, there is a sliding scale present, with some states, including New Jersey and Nebraska, having the mere safeguard to admissibility of the evidence in the form of a caution warning to a jury who are considering the weight to give that evidence (although, in New Jersey, as well as Arkansas, Michigan, Montana, New York, North Carolina and Utah, 59 the absence of a record can be a factor in admissibility arguments, thus mirroring the present law's standing in Northern Ireland and England and Wales). 60

Other states, however, target the admissibility of the confession but do not advocate for automatic exclusion. The District of Columbia Code provides that a statement of an accused taken without the required electronic recording is subject to a rebuttable presumption that the statement was involuntary, and this presumption is overcome if the prosecution proves by clear and convincing evidence that it was voluntary. The same law applies in Illinois. ${ }^{61}$ These are, again, similar provisions to this article's own proposal, although these states do not allow for the automatic exclusion.

The common trend arising out of Alaska and Minnesota, on one side, and the District of Columbia and Illinois, on the other, is that there is a rebuttable presumption in favour of the defendant (be the presumption targeting the admissibility of the surrounding testimony or the confession itself). The examples of these four American jurisdictions therefore presents a third, 'middle-way', approach between the current PACE law in Northern Ireland and England and Wales and this article's proposal. That third approach is that failure to record interviews in compliance with the relevant Codes would not lead to automatic exclusion of the confession, but will instead create a mere presumption as to their exclusion.

The issue, however, with this third middle-way approach, which leads this article to reject such a compromise, is that the middle-way approach of a rebuttable presumption contextualises the voir dire as a balancing act of competing interests. Thus, the protections of the accused under discussion in this article, enshrined within Codes C, E and $\mathrm{F}$, are no longer paramount prerequisites to ensuring reliability of a professed confession, but are instead one of several interests subject to a balancing act, including the interest in a successful prosecution (and so ruling the confession admissible). Yet, this view mischaracterises the question of admissibility as a rights-based question rather than a

59 Bang et al (n 56 above) 14.

60 Sullivan and Vail (n 58 above) 218-219.

61 Ibid. 
question of reliability, 62 and it also mischaracterises the defendant's stake in adherence to Codes $\mathrm{C}, \mathrm{E}$ and $\mathrm{F}$ as an 'interest' rather than as a protection and safeguard to a miscarriage of justice. This difference in characterisation has appropriately been recognised by other commentators. For example, in discussing evidentiary procedure via the lens of a balance of interests, Giannoulopoulos has correctly separated the issue of a defendant's other interests (eg his or her human rights) from confession evidence, which, as has been seen in this article, is inherently unreliable and dangerous. Thus, Giannoulopoulos, in turning his discussion on judicial balance to the question of confessions, relocates the focus from reliable evidence obtained via a breach of the defendant's interests to 'unreliable and intangible evidence', thereby maintaining focus on the fact that confession evidence admissibility is chiefly concerned with reliability as opposed to an 'interest' whose merits can be substantively identified and balanced with other interests. 63

Yet, beyond the argument that the third-way approach mischaracterises the question of exclusion, it could still hypothetically be argued that a presumption as opposed to automatic exclusion can protect the principle of ensuring a confession's reliability, assuming the evidence presented in rebutting the presumption speaks to the issue of reliability and reliability only. However, such a view, it is submitted, exposes the perhaps primary problem in assessing 'reliability' as argued by barristers for the prosecution, and that is the documented underplaying, in empirical psychological evidence, as to the difficulty with which a truly reliable confession can be detected; it cannot be left merely to a judge's balancing act between submissions advanced by the prosecution in rebuttal because the very subject of reliability of confessions is still being expounded upon and explored within psychological literature as a phenomenon that is explained by subtle cognitions of any given suspect, and which may involve confessions which are false, notwithstanding their apparent reliability from a lack of obvious external coercion. ${ }^{64}$ Further still, such a view misses the fact

62 D Ormerod and D Birch, 'The evolution of the discretionary exclusion of evidence' (2004) Criminal Law Review 767, 779; A Ashworth, 'Excluding evidence as protecting rights' (1977) Criminal Law Review 723, 729-733.

63 D Giannoulopoulos, Improperly Obtained Evidence in Anglo-American and Continental Law (Hart 2019) 125.

64 See discussion of the various types of false confessions, some of which may nevertheless seem reliable, in S M Kassin and L S Wrightsman, 'Confession evidence' in S M Kassin and L S Wrightsman (eds), The Psychology of Evidence and Trial Procedure (Sage 1985); J T McCann, 'A conceptual framework for identifying various types of confessions' (1998) 16 Behavioural Sciences and the Law 441; H Wakefield and R Underwager, 'Coerced or nonvoluntary confessions' (1998) 16 Behavioural Sciences and the Law 423. 
that accurate and contemporaneous recording of interviews, enshrined in the Codes, is absolutely crucial to the veracity and reliability of a confession.65 Without those safeguards found in the Codes, the reliability of the confession is automatically undermined. It should therefore automatically be excluded from evidence. This was the view taken by Leo et al in explaining their shift 66 - in the US context from the middle approach of a rebuttable presumption to the view endorsed by this article, namely automatic exclusion. It was also the view of Sullivan and Vail before these two authors began to, instead, argue in favour of a care warning to the jury where an unrecorded confession appears in evidence. Sullivan and Vail have now argued 67 that the trial judge should permit the prosecution to introduce evidence of all unrecorded interviews. If the failure to record is not justified under the law, and if the case is heard by a jury, the judge must give instructions explaining the greater reliability of electronic recordings of custodial interviews as compared to witnesses' testimony about what occurred. This is essentially a reliance on a jury direction as to weight. As aforementioned, this was a reversal of these commentators' previous position, where they advocated for a rule whereby unrecorded interviews are presumed inadmissible into evidence when no statutory exception to the recording requirement applies.68 The reason for the change in opinion was two-fold: first was that provisions that threaten admissibility of testimony about unrecorded interviews are not necessary, in the contributors' determination, in order to achieve compliance with recording laws. This was due to the research undergone that suggested law enforcement agencies were in any event enthusiastic about recordings taking place. Secondly, law enforcement agencies were concerned that criminals would either not be charged or would be acquitted for lack of sufficient evidence of guilt. ${ }^{69}$ While the latter of these arguments has been addressed in this article, it is suggested that, in relation to the first reason, the purpose of the recordings is to protect the accused first and foremost. It is not about 'threatening' law enforcement with inadmissibility of evidence. The courts in this jurisdiction have, as has been seen, made this clear in relation to PACE Code breaches. Subsequently the previous position held by Sullivan and Vail is the preferable view.

65 R Leo, P Neufeld, S Drizin and A Taslitz, 'Promoting accuracy in the use of confession evidence: an argument for pretrial reliability assessments to prevent wrongful convictions' (2013) 85(4) Temple Law Review 759, 799-800.

Ibid.

67 Sullivan and Vail (n 58 above).

68 Sullivan (n 27 above) 1141-1144.

69 Sullivan and Vail (n 58 above) 221-223. 
For the reasons aforementioned, this commentator is not persuaded by the merits of a middle-way approach: a contemporaneous and accurate record of police interviews is the very foundation upon which a resultant confession is considered reliable, without which reliability cannot be effectively gauged by submissions by counsel given what we know about the subtlety of unreliable confessions. It follows that this article maintains the position of advocating for automatic exclusion where such foundations as to reliability are absent.

The illustrated merits of this article's preference for automatic exclusion can be seen through a consideration of the 2020 Court of Appeal in Northern Ireland decision of $R v$ Kevin Barry Artt, which did in fact involve a third-way approach of a presumption in favour of exclusion.

\section{THE TRIAL OF KEVIN BARRY ARTT}

The case at trial of $R v$ Kevin Barry Artt, considered in the context of the 38-defendant trial of $R v$ Donnelly and Others, ${ }^{70}$ was decided six years before the introduction of the Police and Criminal Evidence (Northern Ireland) Order 1989 and before the time of routine video and verbatim transcript recording of interviews. Similar provisions, however, as those found in Code $\mathrm{C}$ had been live at the time of the interviews of the appellant in the form of a certain Royal Ulster Constabulary (RUC) Force Order. ${ }^{71}$ In addition, interviews were to be contemporaneously recorded as per the Judges' Rules, ${ }^{72}$ although it has been outlined that these rules did not amount to 'law' under the common law. ${ }^{73}$ At the time, Castlereagh detention centre had stationary video-recording of interrogation rooms, but no sound was provided.

At trial in 1983, the appellant had denied all involvement in the murder of Albert Miles that had occurred five years previously. The sole evidence against him was a confession statement that the appellant claimed had been made to RUC officers in Castlereagh detention centre while under duress. The appellant claimed he had repeatedly been called a 'bastard' and was verbally abused; he had been told someone had 'squealed' on him; he had been confronted by a co-accused who had falsely implicated him; he had been told other suspects would be turning 'Queen's Evidence' against him at trial; a Detective Inspector and a Detective Chief Superintendent had, on separate occasions, threatened

70 Whilst a neutral citation for this case cannot be located, judgment was delivered in Belfast Crown Court, by Judge Basil Kelly, in August 1983.

71 RUC Force Order No 43/81.

72 Practice Note (Judge's Rules) [1964] 1 WLR 152 (Parker LJ).

73 A Sanders, R Young and M Burton, Criminal Justice 4th edn (University Press 2010) 228. 
to see him rot in jail if he did not confess, whereas he would receive a much shorter sentence if he made a 'good, remorseful statement' with the help of the police, who would then speak on his behalf in court; he had been hit by a Detective Constable after the Detective Constable had told the appellant to pray to God for forgiveness; a newspaper article had been shown to the appellant in order to put pressure on him; and the police had outlined the known facts of the murder to the appellant on multiple occasions. In addition, the appellant was refused access to a solicitor. The RUC officers rejected the appellant's version of events.

The appellant, when asked by the judge why he had made the confession statement, replied that he had thought he had 'no other choice' based on what the police had told him, otherwise he would be going to prison for the rest of his life.

Counsel for the appellant at his trial fought a week-long voir dire in an attempt to get the confession statement excluded from evidence under the high-threshold section 8 of the Northern Ireland (Emergency Provisions) Act 1978, which created a rebuttable presumption in favour of the accused that the confession was obtained by torture, or inhuman or degrading treatment if there was evidence prima facie of same. ${ }^{74}$ Cross-examination of each RUC officer who had interviewed the appellant had it put to them that their denial of the defendant's versions of events was untruthful. One of the questions asked to successive officers was whether or not the interview notes had been contemporaneously recorded. This gave mixed answers, but the majority of officers claimed the interview notes had been made contemporaneously.

The trial judge was left in no doubt that the defendant's case was that the police were lying on oath and so was compelled to believe either the defendant's versions of events or the police's version of events. This inevitably caused him to form an assessment as to the demeanour of each witness.

The trial judge formed a favourable assessment of the RUC witnesses, ruled the confession admissible and, in his judgment, commented that the defendant had told lies about what had occurred in Castlereagh that were 'painfully untrue'. The defendant was sentenced to life imprisonment; however, he became part of the infamous Maze Prison escape in September 1983 - a mere month after sentencing had taken place, thereafter fleeing to America.

74 S 8(2) provided: 'If, in any such proceedings where the prosecution proposes to give in evidence a statement made by the accused, prima facie evidence is adduced that the accused was subjected to torture or to inhuman or degrading treatment in order to induce him to make the statement, the court shall, unless the prosecution satisfies it that the statement was not so obtained-exclude the statement.' 
In 2020, Artt's appeal against conviction and sentence was heard in the Court of Appeal in Northern Ireland and the conviction was quashed on the basis that fresh evidence (namely electrostatic detection apparatus (ESDA)) had shown that some of the RUC interview notes, although not detrimental to the appellant, had been rewritten and were not in any event recorded contemporaneously. Although it was accepted that an innocent explanation for this was plausible, the Court of Appeal had a significant sense of unease over the conviction because the ESDA results demonstrated the possibility that the RUC officers had been untruthful during their evidence in the voir dire. This was accepted by the prosecution before reading of the judgment when senior counsel said:

To put it another way, if the court was to ask me whether I agree-that it is a possibility that if the trial judge had had available to him the ESDA evidence, he would have felt a degree of doubt about his ability to accept the police evidence as to what occurred during the interviews - I would have to answer 'Yes'.75

The appeal judgment continued at paragraph 76:

In order to admit the appellant's confessions, the judge had necessarily to rely heavily on his assessment of the police witnesses as being truthful and reliable. In part that was a comparative exercise in which a diminution of the truthfulness and reliability of the police officers might have led to a more favourable impression as to the truthfulness and reliability of the appellant. If the ESDA evidence had been available to the judge, it remains at least possible that he would have felt a degree of doubt about his ability to accept the evidence of the police officers as opposed to the evidence of the appellant.

It was this uncertainty that gave the Court of Appeal unease as to the safety of the conviction.

The case of Artt highlights the importance that so-called 'boxchecking', regarding recording of interviews in Code $\mathrm{C}, \mathrm{E}$ and $\mathrm{F}$ (or their pre-PACE equivalents), can have once credibility of the police witnesses is brought into dispute. Ensuring interview notes were signed and recorded contemporaneously may not have seemed significant, and though by themselves the ESDA results may have been insignificant in the Artt case, for the Court of Appeal it was the mere possibility that this impacted the credibility of the police officers that led the convictions to be quashed.

Albeit ESDA was not available at the time of trial in 1983, a sign of something not being quite right perhaps raised its head when the RUC Force Order had not been complied with. This ought to have brought up the possibility that the police witnesses were giving untruthful 
evidence during the voir dire. Although this was not the Court of Appeal's conclusion, it is posited that the confession ought to have been excluded at trial as a matter of precaution as soon as this noncompliance was discovered and the credibility of the police became a live issue. It would have been better had the trial judge been able to determine that it was safer to exclude a confession that might have been extracted due to duress rather than to have to form an ad hoc judgment as to a witness's credibility before deciding whom to believe. However, it was not the trial judge's fault in the Artt case that the credibility assessment was wrong, for this assessment was only discovered to be mistaken with the benefit of later scientific technology.

For the law going forward, it is submitted that, post-PACE, and with the benefit of Codes $\mathrm{C}, \mathrm{E}$ and $\mathrm{F}$, if police credibility is challenged, the fact that the Code has been breached should weigh heavily in the defendant's favour and the confession should automatically be excluded. This would ensure that justice is protected against the possibility that the police have told untruths in their evidence in order to secure a wrongful conviction.

Though serving a mere month in prison before his escape, the appellant in the Artt case certainly faced an injustice where the admissibility of a confession, despite warning signs being present in the form of procedural breaches, was decided on the basis of a formulation by the trial judge as to a witness's credibility. For post-PACE cases in which a trial judge must form impressions of the police's credibility versus that of the accused's, the truth of such assessments should not be left to ESDA evidence, which can be expensive to obtain and depends on a number of conditions for the results to be meaningful. Instead, the breaches of the Codes should be what sways the judge's assessment on credibility.

It is of course accepted that trial judges must form impressions of a witness's credibility all the time; the need for this, nor the value of this, cannot, and should not, be eliminated from the trial process. However, what is proposed in this article is a rebalancing of the scales between, on the one hand, a judge's perception of police witnesses' credibility and, on the other hand, factual warning signs as to a police witness's credibility in the form of Code $\mathrm{C}, \mathrm{E}$ and $\mathrm{F}$ breaches. Perception is abundantly less reliable than reality, even for the fairest and most experienced of trial judges.

The adaption of this proposal would not necessarily lead to the accused who is guilty getting off on a technicality; apart from the reasons discussed above as to why the Code provisions in relation to interview recording ought not to be seen as a mere 'technicality', justice and the need to convict the guilty are protected by an important fact: an accused who is indeed guilty usually will have other evidence 
against them merely corroborated by the confession, as opposed to the case against the accused being solely made up by the confession. Even with the confession excluded, then the rest of the evidence may still result in a successful conviction.

Yet, for high-risk prosecutions, such as the Artt case, where the case against the defendant rests solely or substantially on a confession that is rendered dubious according to the defendant's version of events, the risk of a wrongful conviction would be mitigated were the approach suggested in this article adopted. The approach would sit alongside the current law in relation to Code breaches and the admissibility of the confession. The sole criterion for activating this article's approach would be that the credibility of the police witnesses is brought into dispute in relation to the conduct of the interviews and that the circumstances put forward by the accused's version of events would amount to oppression or unreliability. At this stage, in a situation where the trial judge must inevitably believe either the accused or the police witnesses, and being mindful of factual and indisputable Code breaches absent satisfactory explanation, he or she - erring on the side of caution - ought to believe the accused's version of events and subsequently exclude the confession. This would be the best balancing in the competing scales of justice.

\section{CONCLUSION}

This article opened with the proposition that the power of a confession can be such that it is damning to the defence's case in a criminal trial; but that it ought to be potentially damning, too, for the prosecution's case. Yet, in many ways, the need for a confession to be damaging to a prosecution case is greater than its damning power against the defendant, in order to prevent a miscarriage of justice occurring. This article has argued that Codes $\mathrm{C}, \mathrm{E}$ and $\mathrm{F}$ of $\mathrm{PACE}$ in relation to ensuring the accurate recording of interviews is fundamental to ensuring a resultant confession's reliability. For compelling reasons, it has been suggested that a confession, whose very fundamentals of reliability are undermined by a breach of Codes C, E or F, as applicable, ought to be excluded automatically from the evidence if credibility of the police witnesses is raised as a live issue by the defence and the accused's version of events of what went on in the interview room would lead to the resultant confession being made inadmissible.

The first part of this article demonstrated the importance of the Codes in ensuring veracity of the psychological phenomenon of the confession, a creature already notorious in its relatively young literature for being the root cause of miscarriages of justice. This part also examined the suitability of the current PACE statutory framework and jurisprudence 
in combatting a breach of the Codes and found that the decision of a case in this area will typically fall to the discretion of the trial judge. Subsequent appeal has been seen to be hopeless. The second part of the article examined the main objections against an expansion of the law, and the chief objection - that this article's proposal would lead to injustices in guilty defendants walking free on account of a mere technicality - was discounted for two reasons: firstly, the requirements of Codes C, E and F are far from a mere technicality, but absolutely crucial to a confession's reliability. Secondly, any prosecution which is strong will have evidence beyond the confession statement, which should on its own merits convict the accused if justice so allows. The third part of the article turned the discussion away from criticisms and to the merits of the article's proposal. It demonstrated that the even greater injustice of the innocent being convicted on the basis of a dubious confession would be mitigated against were the article's proposals adopted. An examination of the US jurisdictions demonstrated a test course for the proposals, but in subtly different ways, including the trend of some states in creating a rebuttable presumption for exclusion as opposed to automatic exclusion. This 'third-way' approach was examined as a potential compromise but ultimately rejected on the basis that the Codes' procedural requirements secure the absolute essentials of a reliable confession, whose absence cannot be reconciled by the arguments and assurances by the prosecution. Part four saw a practical application of the third-way approach in the Northern Ireland jurisdiction in the form of the Northern Ireland (Emergency Provisions) Act 1978, under which the admissibility of the confession in the 1983 case of $R v$ Kevin Barry Artt was decided. This case demonstrated the need for automatic exclusion, a rejection of the third-way approach, and a reform to the current PACE jurisprudence that deals with breaches of the Codes in relation to the recording of interviews.

One need only consider the Salem Witch Trials in appreciating the power a confession has had throughout history, but also the power of its obvious pitfalls. Given the serious implications of those pitfalls, automatic exclusion of the confession statement where credibility of the police is brought into question is the safest method of ensuring that miscarriages of justice such as the case of Kevin Barry Artt cannot be repeated. 